\title{
Pseudomonas cuatrocienegasensis sp. nov., isolated from an evaporating lagoon in the Cuatro Ciénegas valley in Coahuila, Mexico
}

Correspondence

Valeria Souza

souza@servidor.unam.mx
Ana E. Escalante, ${ }^{1}$ Jesús Caballero-Mellado, ${ }^{2}$ Lourdes Martínez-Aguilar, ${ }^{2}$ Alejandra Rodríguez-Verdugo, ${ }^{1}$ Andrea González-González, ${ }^{1}$ Jeiry Toribio-Jiménez ${ }^{3}$ and Valeria Souza ${ }^{1}$

\author{
${ }^{1}$ Departamento de Ecología Evolutiva, Instituto de Ecología, Universidad Nacional Autónoma de \\ México, Apartado Postal 70-275, México DF 04510, Mexico \\ ${ }^{2}$ Programa de Ecología Genómica, Centro de Ciencias Genómicas, Universidad Nacional Autónoma \\ de México, Apartado Postal 565-A, Cuernavaca, Morelos, Mexico \\ ${ }^{3}$ Departamento de Biología Molecular y Biotecnología, Instituto de Investigaciones Biomédicas, \\ Universidad Nacional Autónoma de México, Apartado Postal 70-275, DF, Mexico
}

\begin{abstract}
Nine Gram-negative, rod-shaped, non-spore-forming isolates with identical or very similar repetitive-sequence-based PCR profiles were recovered from an evaporative lagoon in Mexico. Two strains, designated $1 \mathrm{~N}^{\top}$ and $3 \mathrm{~N}$, had virtually identical 16S rRNA gene sequences and, on the basis of these sequences, were identified as members of the genus Pseudomonas, with Pseudomonas peli $\mathrm{R}-20805^{\top}$ as the closest relative. All nine isolates had practically identical whole-cell protein profiles. The major fatty acids $\left[\mathrm{C}_{16: 0}, \mathrm{C}_{18: 1} \omega 7 \mathrm{c}\right.$ and summed feature a $\left(\mathrm{C}_{16: 1} \omega 7\right.$ and/or $\left.\left.\mathrm{C}_{16: 1} \omega 6 \mathrm{c}\right)\right]$ of strains $1 \mathrm{~N}^{\top}$ and $3 \mathrm{~N}$ supported their affiliation with the genus Pseudomonas. The DNA-DNA reassociation values with respect to $P$. peli LMG $23201^{\top}$ and other closely related Pseudomonas species were $<15 \%$. Physiological and biochemical tests allowed phenotypic differentiation of the strains analysed, including strain $1 \mathrm{~N}^{\top}$, from the five phylogenetically closest Pseudomonas species. On the basis of the data obtained by using this polyphasic taxonomic approach, the nine strains represent a novel species, for which the name Pseudomonas cuatrocienegasensis sp. nov. is proposed. The type strain is $1 \mathrm{~N}^{\top}$ (=LMG $24676^{\top}=$ CIP $109853^{\top}$ ).
\end{abstract}

The genus Pseudomonas was described by Migula (1894). Since then, there has been a steady increase in the rate of description of species belonging to the genus Pseudomonas; there are currently more than 191 species with validly published names (Anzai et al., 2000; http://www.dsmz.de/ microorganisms/bacterial_nomenclature.php). Pseudomonas species are ubiquitous in nature and can be isolated from humans, clinical samples, the plant rhizosphere, soil and water (including seawater) (Spiers et al., 2000; Yamamoto et al., 2000; Moore et al., 2006).

In the present study, a polyphasic approach was undertaken to determine the taxonomic status of nine isolates recovered from an evaporative lagoon in the

The GenBank/EMBL/DDBJ accession numbers for the 16S rRNA sequences of strains $1 N^{\top}$ and $3 N$ are EU791281 and EU791282, respectively.

A figure showing a pulsed-field electrophoresis gel of novel strains described in this work and type and reference strains of known Pseudomonas species is available with the online version of this paper.
Churince system, a hydrological system in the Cuatro Ciénegas valley in Coahuila, Mexico $\left(26^{\circ} 50.830^{\prime} \mathrm{N} 102^{\circ}\right.$ $\left.09.335^{\prime} \mathrm{W}\right)$.

A large collection of bacterial isolates was obtained from surface water samples collected at two different points (10 $\mathrm{m}$ apart) in the lagoon referred to as Laguna Grande. Water samples $(15 \mathrm{ml})$ from each site were collected in sterile BD Falcon vials (BD Biosciences) and $200 \mu \mathrm{l}$ from each sample was inoculated on glutamate/starch/phenol red (GSP) agar plates (Kielwein, 1971). The GSP medium had the following composition $\left(\mathrm{g} \mathrm{l}^{-1}\right)$ : sodium $\mathrm{L}-(+)$ glutamate, 10.0; starch (soluble), 20.0; potassium dihydrogen phosphate, 2.0; magnesium sulfate, 0.5 ; phenol red, 0.36; agar-agar, 12.0). Incubation was performed at $29{ }^{\circ} \mathrm{C}$ for $48 \mathrm{~h}$. Colonies grown on different GSP plates were purified by subculture on Luria-Bertani (LB) agar (1\% tryptone, $0.5 \%$ yeast extract, $1 \% \mathrm{NaCl}$ and $1.5 \%$ agar) plates and the cultures were maintained at $-80{ }^{\circ} \mathrm{C}$ in $\mathrm{LB}$ broth ( $1 \%$ tryptone, $0.5 \%$ yeast extract and $1 \% \mathrm{NaCl}$ ) with $20 \%(\mathrm{w} / \mathrm{v})$ glycerol prior to analysis. 
Isolates were grown in $5 \mathrm{ml} \mathrm{LB}$ broth. DNA was extracted by using a DNeasy Blood and Tissue kit (Qiagen) according to the manufacturer's instructions. Repetitivesequence-based PCR profiles of the isolates and reference strains were determined with BOX primers and conditions as described by Versalovic et al. (1991, 1994). The PCR conditions consisted of an initial denaturing step at $95{ }^{\circ} \mathrm{C}$ for $7 \mathrm{~min}, 30$ cycles of $94{ }^{\circ} \mathrm{C}$ for $1 \mathrm{~min}, 53{ }^{\circ} \mathrm{C}$ for $1 \mathrm{~min}$, $65{ }^{\circ} \mathrm{C}$ for $8 \mathrm{~min}$ and a final extension at $65{ }^{\circ} \mathrm{C}$ for $8 \mathrm{~min}$. The PCR products were electrophoresed in $1.5 \%$ agarose gels $(0.5 \times$ TAE buffer; $2.42 \mathrm{~g}$ Tris- $\mathrm{HCl}, 0.57 \mathrm{ml}$ glacial acetic acid, $1 \mathrm{ml} 0.5 \mathrm{M}$ EDTA ( $\mathrm{pH} 8.0$ ) and 11 distilled and deionized water) for $5 \mathrm{~h}$ at $180 \mathrm{mV}\left(5 \mathrm{~V} \mathrm{~cm}^{-1}\right)$. The gels were stained with ethidium bromide and a digital image was obtained for further analysis. Isolates that displayed the same number of bands and similar fragment sizes were considered identical and therefore belonging to the same bacterial group or genotype. On this basis, nine isolates recovered from different water samples were identified as having identical (or very similar) repetitivesequence-based PCR patterns (data not shown). 16S rRNA gene sequences were obtained from two of these strains, namely $1 \mathrm{~N}^{\mathrm{T}}$ and $3 \mathrm{~N}$, in order to define their taxonomic affiliation. The almost-complete 16S rRNA gene sequences were obtained by PCR amplification using primers 27F and $1492 \mathrm{R}$ and the conditions described previously (Lane, 1991). 16S rRNA gene sequences (approx. $1450 \mathrm{bp)}$ ) were obtained (High-Throughput Sequencing Enterprise of the University of Washington, USA) and were compared with all publicly available complete $16 \mathrm{~S}$ rRNA gene sequences of the type strains of Pseudomonas species with validly published names, using the Ribosomal Database Project (RDP) II database and software (Cole et al., 2007). An analysis based on $16 \mathrm{~S}$ rRNA gene sequence similarities indicated that the closest relatives of strain $1 \mathrm{~N}^{\mathrm{T}}$ were Pseudomonas peli R-20805 ${ }^{\mathrm{T}}$ (98.5\%), Pseudomonas argentinensis $\mathrm{CHO1}^{\mathrm{T}}(97.5 \%)$, Pseudomonas flavescens $\mathrm{B}^{\mathrm{T}}{ }^{\mathrm{T}}$ $(97.4 \%)$ and Pseudomonas anguilliseptica NCIMB $1949^{\mathrm{T}}$ (97.4\%). Recently, two novel Pseudomonas species, Pseudomonas guineae and Pseudomonas marincola, were described (Bozal et al., 2007; Romanenko et al., 2008) that showed 97.9 and $97.6 \%$ identity, respectively, with respect to strain $1 \mathrm{~N}^{\mathrm{T}}$. The phylogenetic tree based on $16 \mathrm{~S}$ rRNA gene sequences (Fig. 1) illustrates the position of strains $\mathrm{IN}^{\mathrm{T}}$ and $3 \mathrm{~N}$ relative to members of Pseudomonas species; both strains clustered within a single group that was clearly separated from the cluster formed by the closely related type strains of the species $P$. peli, $P$. anguilliseptica and $P$. guineae, and from the clusters formed by the type strains of Pseudomonas borbori, P. marincola, Pseudomonas segetis, P. argentinensis and $P$. flavescens. These data suggested that the nine isolates analysed in the present study might constitute a novel Pseudomonas species.

The preparation of whole-cell proteins from all of the isolates and SDS-PAGE assays were performed as described previously (Estrada-De Los Santos et al., 2001). The Pseudomonas isolates recovered from the lagoon shared almost-identical protein profiles, but their protein patterns were notably different from those of $P$. anguilliseptica LMG $21629^{\mathrm{T}}$ and P. peli LMG $23201^{\mathrm{T}}$, as well as from those of representatives of other closely related Pseudomonas species (Fig. 2). It has previously been noted that bacteria with identical or similar protein patterns possess high levels of genome similarity (Vandamme et al., 1996). On this basis, the SDS-PAGE results strongly suggested that all of the isolates represented a novel Pseudomonas species.

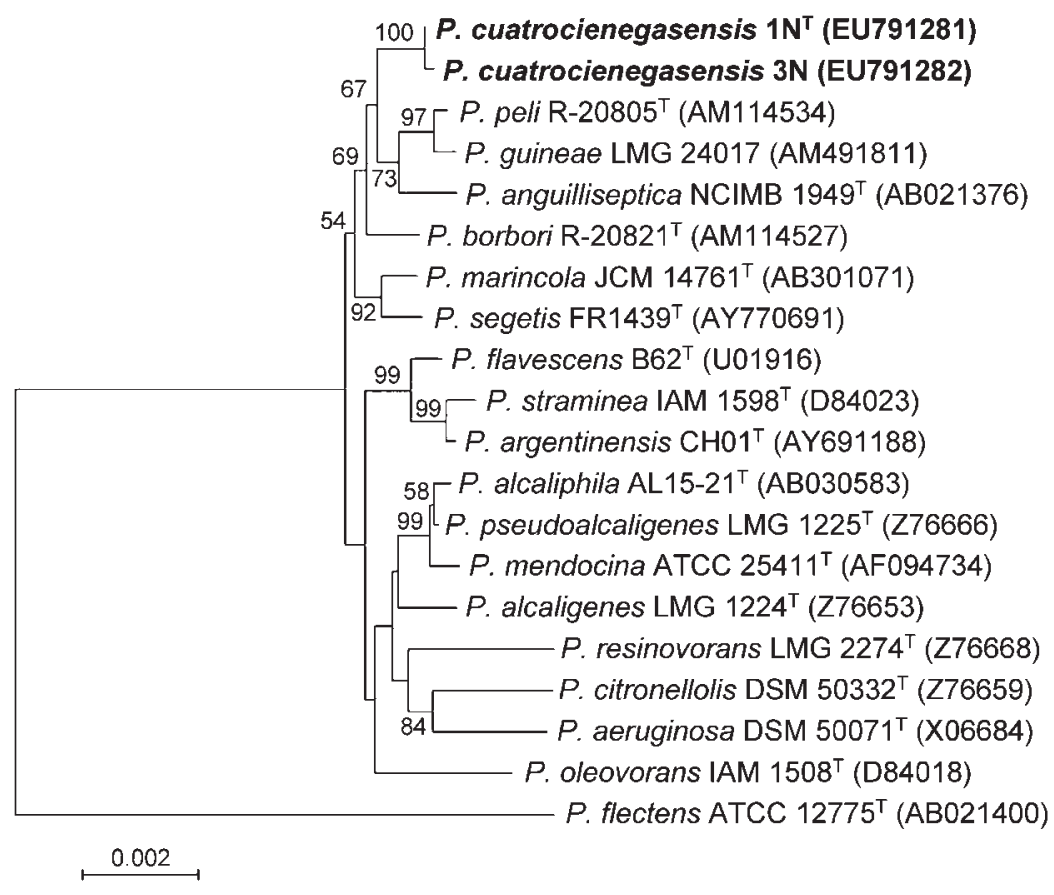

Fig. 1. Phylogenetic tree, based on Kimura two-parameter distances and neighbour-joining clustering after multiple alignment $(1480 \mathrm{bp})$ of the $16 \mathrm{~S}$ rRNA gene sequences of strains $\mathbb{I N}^{\top}$ and $3 \mathrm{~N}$ and the most closely related members of the genus Pseudomonas. Bootstrap percentages (based on 1000 replications) $>50 \%$ are shown at branch points. The phylogenetic analysis was performed by using the software package MEGA, version 3.1 (Kumar et al., 2004). The unweighted pair group method with arithmetic averages and the maximum-parsimony method were also used and gave approximately the same results, with the same clustering of the novel strains. Bar, 0.002 substitutions per site. 
(a)

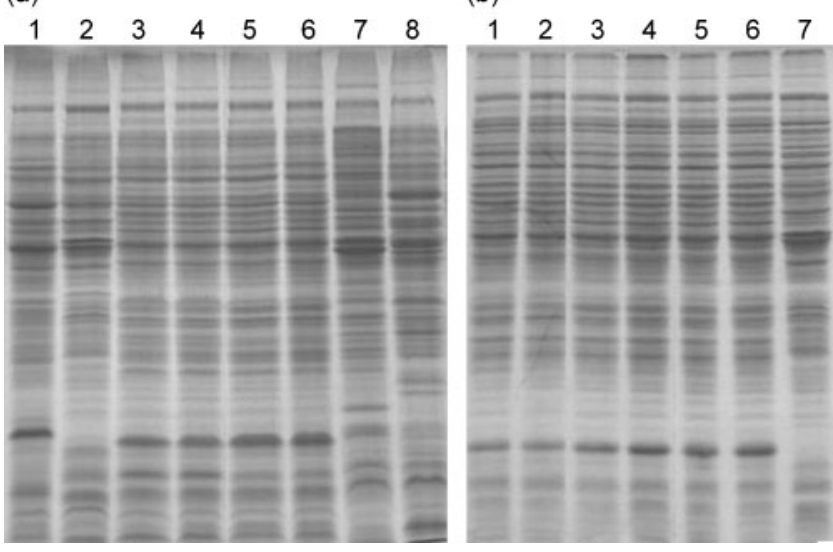

Fig. 2. Whole-cell protein profiles of strains $1 N^{\top}, 11 N, 10 N$ and $9 \mathrm{~N}$ and of type strains of known Pseudomonas species. (a) Lanes: 1, P. anguilliseptica LMG $21629^{\top} ; 2$, P. peli LMG $23201^{\top} ; 3-6$, strains $1 \mathrm{~N}^{\top}, 11 \mathrm{~N}, 10 \mathrm{~N}$ and $9 \mathrm{~N}$, respectively; $7, P$. stutzeri LMG $11199^{\top}$; $8, P$. flavescens LMG $18387^{\top}$. (b) Lanes: $1-6$, strains $1 \mathrm{~N}^{\top}, 3 \mathrm{~N}, 2 \mathrm{~N}, 9 \mathrm{~N}, 8 \mathrm{~N}$ and $6 \mathrm{~N}$, respectively; 7, P. peli LMG $23201^{\top}$.

For qualitative and quantitative analysis of the cellular fatty acids, strains $\mathrm{IN}^{\mathrm{T}}$ and $3 \mathrm{~N}$ were cultivated on tryptic soy agar (Sigma-Aldrich) for 2 days at $28{ }^{\circ} \mathrm{C}$. The whole-cell fatty acid compositions were determined by using an Agilent 6850 gas chromatograph (Agilent Technologies) and the fatty acid methyl esters were analysed by using the Sherlock 4.5 Microbial Identification System (Microbial ID). The fatty acid compositions of strains $1 \mathrm{~N}^{\mathrm{T}}$ and $3 \mathrm{~N}$, together with typestrain data for their closest phylogenetic relatives, are shown in Table 1 . The major fatty acid composition supports the affiliation of strains $1 \mathrm{~N}^{\mathrm{T}}$ and $3 \mathrm{~N}$ to the genus Pseudomonas; in addition, there are differences in the relative abundance of fatty acids with respect to the type strains of $P$. anguilliseptica, P. flavescens, P. guineae and P. peli. Strains $1 \mathrm{~N}^{\mathrm{T}}$ and $3 \mathrm{~N}$ exhibit clear quantitative differences for $\mathrm{C}_{12: 0}, \mathrm{C}_{12: 0} 3-\mathrm{OH}$ and $\mathrm{C}_{16: 0}$ with respect to the type strains of their closest relatives, i.e. $P$. anguilliseptica, $P$. marincola, $P$. guineae and $P$. peli. In addition, these strains exhibit summed feature a $\left(\mathrm{C}_{16: 1} \omega 7\right.$ and/or $\left.\mathrm{C}_{16: 1} \omega 6 c\right)$, which is not present in the closely related species (Table 1). Although most of the fatty acids reported previously for the most closely related Pseudomonas species are present in the profiles of strains $1 \mathrm{~N}^{\mathrm{T}}$ and $3 \mathrm{~N}$, the absence of an unknown fatty acid (equivalent chain length 11.799) and the fatty acid components of summed feature $b\left(\mathrm{C}_{16: 1} \omega 7\right.$ and/or iso$\mathrm{C}_{15: 0}$ 2-OH) is noteworthy. Special caution should be exercised with regard to comparison of the fatty acid profiles of $1 \mathrm{~N}^{\mathrm{T}}$ and $3 \mathrm{~N}$ with that of $P$. guineae $\mathrm{M}^{\mathrm{T}}$, as the latter was grown for 4 days at $15{ }^{\circ} \mathrm{C}$ before the fatty acid analysis, and this is not typical of the standard temperature ranges used for this type of analysis in members of the genus Pseudomonas.

To clarify the taxonomic relationships at species level, DNA-DNA hybridization experiments were performed as described previously (Estrada-De Los Santos et al., 2001); the analysis was based on relative levels of hybridization to ${ }^{32}$ P-labelled DNA from strain $1 \mathrm{~N}^{\mathrm{T}}$. DNA-DNA relatedness assays were performed with four strains recovered from the lagoon, with the type strain of the most closely related Pseudomonas species (as indicated by 16S rRNA gene sequence data) and with the type strain of Pseudomonas stutzeri, which has a fatty acid profile very similar to those of $1 \mathrm{~N}^{\mathrm{T}}$ and $3 \mathrm{~N}$ according to the database of the Microbial

Table 1. Cellular fatty acid compositions of strains $1 \mathrm{~N}^{\top}$ and $3 \mathrm{~N}$ and strains of the most closely related Pseudomonas species

Taxa: 1, strain $1 \mathrm{~N}^{\mathrm{T}} ; 2$, strain $3 \mathrm{~N} ; 3$, P. peli (LMG $23201^{\mathrm{T}}$ and R-20815); 4, P. anguilliseptica LMG $21629^{\mathrm{T}} ; 5$, P. guineae (three replicate readings of M8 $\left.{ }^{\mathrm{T}}\right) ; 6$, P. marincola JCM $14761^{\mathrm{T}} ; 7$, P. flavescens LMG $18387^{\mathrm{T}}$. Data for P. peli, P. anguilliseptica and P. flavescens were taken from Vanparys et al. (2006), values for P. guineae were taken from Bozal et al. (2007) and values for P. marincola were taken from Romanenko et al. (2008). Results for groups of strains are expressed as means (with SD in parentheses). tr, Trace $(<0.1 \%)$; -, not detected.

\begin{tabular}{|c|c|c|c|c|c|c|c|}
\hline Fatty acid & 1 & 2 & 3 & 4 & 5 & 6 & 7 \\
\hline $\mathrm{C}_{10: 0} 3-\mathrm{OH}$ & 3.11 & 3.17 & $4.10(0.23)$ & 3.17 & $3.47(0.58)$ & 5.7 & 5.23 \\
\hline Unknown (ECL 11.799)* & - & - & $4.01(0.06)$ & 3.14 & $3.70(0.39)$ & 1.2 & $\operatorname{tr}$ \\
\hline $\mathrm{C}_{12: 0}$ & 8.08 & 8.08 & 4.92 & 3.87 & $3.99(0.49)$ & 13.2 & 11.7 \\
\hline $\mathrm{C}_{12: 0} 3-\mathrm{OH}$ & 3.69 & 3.67 & $4.17(0.28)$ & 2.7 & $3.61(0.28)$ & 3.7 & 4.85 \\
\hline $\mathrm{C}_{16: 0}$ & 14.85 & 15.16 & $10.01(0.04)$ & 23.17 & $10.92(3.08)$ & 20.2 & 19.15 \\
\hline $\mathrm{C}_{16: 1}$ & - & - & - & - & - & 18.6 & - \\
\hline $\mathrm{C}_{17: 1} \omega 8 c$ & $\operatorname{tr}$ & $\operatorname{tr}$ & $3.17(0.04)$ & $\operatorname{tr}$ & $\operatorname{tr}$ & 3.7 & $\operatorname{tr}$ \\
\hline $\mathrm{C}_{18: 0}$ & 1.03 & 1.00 & $\operatorname{tr}$ & $\operatorname{tr}$ & $\operatorname{tr}$ & - & $\operatorname{tr}$ \\
\hline $\mathrm{C}_{18: 1} \omega 7 c$ & 31.29 & 31.46 & $26.53(0.61)$ & 33.57 & $31.02(1.08)$ & 32.1 & 33.82 \\
\hline \multicolumn{8}{|l|}{ Summed features $\dagger$} \\
\hline $\mathrm{a}$ & 34.79 & 34.70 & - & - & - & - & 22.07 \\
\hline $\mathrm{b}$ & - & - & 27.55 & 26.81 & $37.81(1.33)$ & - & - \\
\hline
\end{tabular}

${ }^{\star} \mathrm{ECL}$, Equivalent chain length.

†Summed features: a, $\mathrm{C}_{16: 1} \omega 7 c$ and/or $\mathrm{C}_{16: 1} \omega 6 c$; b, $\mathrm{C}_{16: 1} \omega 7 c$ and/or iso- $\mathrm{C}_{15: 0}$ 2-OH. 
Table 2. Enzyme activity and assimilation of carbon sources

Taxa: $1,1 \mathrm{~N}^{\mathrm{T}}$; 2, 3N; 3, P. peli LMG $23201^{\mathrm{T}}$; 4, P. guineae $\mathrm{M8}^{\mathrm{T}}$; 5, $P$. anguilliseptica LMG $21629^{\mathrm{T}} ; 6$, P. marincola JCM $14761^{\mathrm{T}} ; 7, P$. flavescens $\mathrm{LMG} 1837^{\mathrm{T}}$. All strains were positive for oxidase and catalase activity and for assimilation of malate. All strains were negative for the following: indole formation, fermentative acid production from glucose, urease, hydrolysis of aesculin and gelatin, $\beta$-galactosidase, $\mathrm{N}$-acetylglucosamine and assimilation of D-ribose, maltose, adipate, erythritol, D-arabinose, L-xylose, D-adonitol, methyl $\beta$-D-xylopyranoside, L-sorbose, dulcitol, inositol, D-sorbitol, methyl $\alpha$-D-glucopyranoside, methyl $\alpha$-D-mannopyranoside, amygdalin, arbutin, aesculin, ferric citrate, salicin, cellobiose, D-lactose (bovine origin), melibiose, D-sucrose, inulin, melezitose, raffinose, starch, glycogen, xylitol, gentiobiose, turanose, D-lyxose, D-tagatose, L-fucose, D-arabitol, L-arabitol and 5-ketogluconate. Data for P. guineae were taken from Bozal et al. (2007) and data for P. marincola were taken from Romanenko et al. (2008). NA, Data not available; w, weakly positive; + , positive; - , negative.

\begin{tabular}{|c|c|c|c|c|c|c|c|}
\hline Characteristic & 1 & 2 & 3 & 4 & 5 & 6 & 7 \\
\hline Fluorescent pigments & - & - & - & - & - & - & + \\
\hline \multicolumn{8}{|l|}{ Enzyme activity: } \\
\hline Nitrate reduction & - & - & - & + & - & + & - \\
\hline Arginine dihydrolase & - & - & - & - & - & + & \\
\hline \multicolumn{8}{|l|}{ Assimilation of: } \\
\hline D-Glucose & - & - & - & - & - & - & + \\
\hline Trehalose & - & - & - & - & - & - & + \\
\hline L-Arabinose & - & - & - & - & - & - & + \\
\hline D-Mannose & - & - & - & - & - & - & + \\
\hline D-Mannitol & - & - & - & - & - & - & + \\
\hline Caprate & + & + & - & + & + & + & + \\
\hline Citrate (trisodic) & + & + & - & + & + & + & - \\
\hline Glycerol & - & - & - & - & - & - & + \\
\hline D-Xylose & + & + & - & - & - & - & - \\
\hline D-Galactose & - & - & - & + & - & - & + \\
\hline D-Fructose & - & - & - & - & - & NA & $\mathrm{w}$ \\
\hline D-Mannose & - & - & - & - & - & - & + \\
\hline L-Rhamnose & + & + & - & - & - & - & - \\
\hline D-Mannitol & - & - & - & - & - & - & + \\
\hline D-Fucose & + & + & - & - & - & - & - \\
\hline Potassium gluconate & + & + & - & - & - & - & + \\
\hline Potassium 2-ketogluconate & - & + & - & - & - & - & - \\
\hline Phenyl acetate & - & - & - & - & - & + & - \\
\hline
\end{tabular}

Identification System (Microbial ID). The DNA-DNA reassociation values between the strains recovered from the lagoon were in the range $87-99 \%(3 \mathrm{~N}, 87 \% ; 2 \mathrm{~N}, 96 \% ; 5 \mathrm{~N}$, $97 \%$ ), indicating close relationships at the species level (Vandamme et al., 1996; Stackebrandt et al., 2002). In contrast, low reassociation values $(<15 \%)$ were obtained in hybridizations of strain $1 \mathrm{~N}^{\mathrm{T}}$ with P. peli LMG $23201^{\mathrm{T}}$ (14\%), P. anguilliseptica LMG $21629^{\mathrm{T}}(14 \%)$, P. flavescens LMG $18387^{\mathrm{T}}(13 \%)$ and P. stutzeri LMG $11199^{\mathrm{T}}(12 \%)$. These DNA-DNA reassociation data, together with the $16 \mathrm{~S}$ rRNA gene sequence results, as well as the SDS-PAGE protein patterns and the fatty acid profiles, support the notion that the isolates recovered from the evaporating lagoon represent a novel species of the genus Pseudomonas, for which the name Pseudomonas cuatrocienegasensis sp. nov. is proposed.

To estimate the genome size of $P$. cuatrocienegasensis $\mathrm{sp}$. nov., strains $1 \mathrm{~N}^{\mathrm{T}}, 2 \mathrm{~N}, 3 \mathrm{~N}, 6 \mathrm{~N}, 8 \mathrm{~N}, 9 \mathrm{~N}, 10 \mathrm{~N}$ and $11 \mathrm{~N}$ were analysed by PFGE with I-CeuI endonuclease. Genomic DNA preparation and digestion of whole genomes were carried out as described by Liu et al. (1993) and Matushek et al. (1996), but with some modifications in the DNAextraction procedure [3 h lysis time instead of overnight; two overnight washes of the lysed product instead of one; and eight washes with TE (10 mM Tris-Cl, pH 7.5; $1 \mathrm{mM}$ EDTA) instead of two]. For P. cuatrocienegasensis sp. nov., the mean genome size was $2995 \pm 663 \mathrm{~kb}$, which is similar to those of $P$. peli LMG $23201^{\mathrm{T}}(3450 \mathrm{~kb})$ and $P$. flavescens LMG $18387^{\mathrm{T}}(2665 \mathrm{~kb})$, but much smaller than that of $P$. aeruginosa PAO1 $(6262 \mathrm{~kb})$. Four RNA operons were detected in $P$. cuatrocienegasensis sp. nov. strain $1 \mathrm{~N}^{\mathrm{T}}$ (Supplementary Fig. S1, available in IJSEM Online).

Bacteriological and biochemical characterization of the novel isolates was carried after growth in LB medium for $48-72 \mathrm{~h}$ at $29{ }^{\circ} \mathrm{C}$. The production of fluorescent pigments was tested on King's B medium (King et al., 1954). Other phenotypic features were assayed with the API 20NE and API 50CH systems according to the instructions of the manufacturer (bioMérieux). The API 20NE system was used to determine nitrate reduction, gelatin liquefaction, aesculin hydrolysis, urease activity, indole production, fermentative acid production from glucose, $\beta$-galactosidase activity and arginine dihydrolase activity. All colonies were grown on LB agar plates to determine the oxidase reaction as a complementary test in the API 20NE system. The utilization of various carbon sources was tested by using the API $50 \mathrm{CH}$ system after incubation for $72 \mathrm{~h}$ at $29{ }^{\circ} \mathrm{C}$. The inoculation medium used for the API $50 \mathrm{CH}$ test strips was $\mathrm{CHB} / \mathrm{E}\left[1^{-1}\right.$ : ammonium sulfate $(2 \mathrm{~g})$, yeast extract $(0.5 \mathrm{~g})$, tryptone $(1 \mathrm{~g})$, disodium phosphate $(3.22 \mathrm{~g})$, monopotassium phosphate $(0.12 \mathrm{~g})$, trace elements $(10 \mathrm{ml})$, phenol red $(0.17 \mathrm{~g})$; $\mathrm{pH} 7.4-7.8]$; the incubation was performed at $20-25{ }^{\circ} \mathrm{C}$. The results of these tests showed that the strains of $P$. cuatrocienegasensis sp. nov. differ from the most closely related species in terms of the utilization of specific carbon sources, e.g. D-xylose, Dfucose and gluconate; complete data are shown in Table 2.

\section{Description of Pseudomonas cuatrocienegasensis sp. nov.}

Pseudomonas cuatrocienegasensis (cu.a.tro.cie.ne.gas.en'sis. N.L. fem. adj. cuatrocienegasensis pertaining to the Cuatro Ciénegas valley, the location of the evaporative lagoon from which the organism was isolated).

Cells are rods $(1.2 \pm 0.13 \mu \mathrm{m}$ long and $0.53 \pm 0.02 \mu \mathrm{m}$ wide) that are motile by means of a single, polar flagellum. Gram-negative, oxidase-positive and catalase-positive. Good growth occurs on LB agar and GSP agar at 28$32{ }^{\circ} \mathrm{C}$; colonies on LB agar are beige, mucoid and irregular. 
No production of fluorescent pigments is observed in King's $\mathrm{B}$ medium. The major fatty acids in the type strain are $\mathrm{C}_{16: 0}$ $(14.85 \%), \mathrm{C}_{18: 1} \omega 7 c(31.29 \%)$ and summed feature a $\left(\mathrm{C}_{16: 1} \omega 7 c\right.$ and/or $\left.\mathrm{C}_{16: 1} \omega 6 c, 34.79 \%\right)$; in addition, $\mathrm{C}_{12: 0}$ (8.08\%), $\mathrm{C}_{12: 0} 3-\mathrm{OH}(3.69 \%), \mathrm{C}_{10: 0} 3-\mathrm{OH}(3.11 \%), \mathrm{C}_{18: 0}$ $(1.03 \%)$ and $\mathrm{C}_{17: 1} \omega 8 c(<1 \%)$ are detected. It is noteworthy that strains $1 \mathrm{~N}^{\mathrm{T}}$ and $3 \mathrm{~N}$ lack an unknown fatty acid (equivalent chain length 11.799) that is present in type strains of all of the most closely related species. The carbon sources utilized are indicated in Table 2. The utilization of Dxylose, L-rhamnose, D-fucose and potassium gluconate serve as differential characteristics for this species.

The type strain, $1 \mathrm{~N}^{\mathrm{T}}\left(=\mathrm{LMG} 24676^{\mathrm{T}}=\mathrm{CIP} 109853^{\mathrm{T}}\right)$, was isolated from an evaporative lagoon in Cuatro Ciénegas, Coahuila State, Mexico.

\section{Acknowledgements}

We thank R. González-Chauvet (Biósfera-UNO, México), G. M. Rosas-Barrera (Instituto de Ecología, UNAM, México), A. Casamitjana and the Modern American School (México) for sample collection and technical assistance. We gratefully acknowledge Bulmaro Reyes-Coria (Instituto de Investigaciones Filologicas, UNAM, México), Jean Euzéby (Ecole Nationale Vétérinaire, Toulouse, France) and Bernhard Schink (Universität Konstanz, Germany) for help with the etymological construction of the novel species name, G. Delgado-Sapien (Facultad de Medicina, UNAM, México) for assistance with the molecular techniques, A. PatrónSoberano (Instituto de Fisiología Celular, UNAM, México) for the micrographs and L. E. Eguiarte (Instituto de Ecología, UNAM, México) for comments and ideas. This project was supported by grants from SEMARNAT/CONACyT to V.S. (2002-CO1-0246) and by a CONACyT-UNAM scholarship to A. E. E.

\section{References}

Anzai, Y., Kim, H., Park, J.-Y., Wakabayashi, H. \& Oyaizu, H. (2000). Phylogenetic affiliation of the pseudomonads based on 16S rRNA sequence. Int J Syst Evol Microbiol 50, 1563-1589.

Bozal, N., Montes, M. J. \& Mercadé, E. (2007). Pseudomonas guineae sp. nov., a novel psychrotolerant bacterium from an Antarctic environment. Int J Syst Evol Microbiol 57, 2609-2612.

Cole, J. R., Chai, B., Farris, R. J., Wang, Q., Kulam-Syed-Mohideen, A. S., McGarrell, D. M., Bandela, A. M., Cardenas, E., Garrity, G. M. \& Tiedje, J. M. (2007). The ribosomal database project (RDP-II): introducing myRDP space and quality controlled public data. Nucleic Acids Res 35 (Database issue), D169-D172.

Estrada-De Los Santos, P., Bustillos-Cristales, R. \& CaballeroMellado, J. (2001). Burkholderia, a genus rich in plant-associated nitrogen fixers with wide environmental and geographic distribution. Appl Environ Microbiol 67, 2790-2798.
Kielwein, G. (1971). Die Isolierung und Differenzierung von Pseudomonaden aus Lebensmitteln. Arch Lebensmittelhyg 22, 29-37 (in German).

King, E. O., Ward, M. K. \& Raney, D. E. (1954). Two simple media for the demonstration of pycocyanin and fluorescein. J Lab Clin Med 44, 301-307.

Kumar, S., Tamura, K. \& Nei, M. (2004). MEGA3: integrated software for molecular evolutionary genetics analysis and sequence alignment. Brief Bioinform 5, 150-163.

Lane, D. J. (1991). 16S/23S rRNA sequencing. In Nucleic Acid Techniques in Bacterial Systematics, pp. 115-175. Edited by E. Stackebrandt \& M. Goodfellow. Chichester, UK: Wiley.

Liu, S. L., Hessel, A. \& Sanderson, K. E. (1993). Genomic mapping with I-Ceu I, an intron-encoded endonuclease specific for genes for ribosomal RNA, in Salmonella spp., Escherichia coli, and other bacteria. Proc Natl Acad Sci U S A 90, 6874-6878.

Matushek, M. G., Bonten, M. J. \& Hayden, M. K. (1996). Rapid preparation of bacterial DNA for pulsed-field gel electrophoresis. J Clin Microbiol 34, 2598-2600.

Migula, W. (1894). Über ein neues System der Bakterien. Arb Bakteriol Inst Karlsruhe 1, 235-238 (in German).

Moore, E. R. B., Tindall, B. J., Martins Dos Santos, V. P., Pieper, D. H., Ramos, J.-L. \& Palleroni, N. (2006). Nonmedical Pseudomonas. In The Prokaryotes: a Handbook on the Biology of Bacteria, pp. 643-703. Edited by M. Dworkin and others. New York: Springer.

Romanenko, L. A., Uchino, M., Tebo, B. M., Tanaka, N., Frolova, G. M. \& Mikhailov, V. V. (2008). Pseudomonas marincola sp. nov., isolated from marine environments. Int J Syst Evol Microbiol 58, 706-710.

Spiers, A. J., Buckling, A. \& Rainey, P. (2000). The causes of Pseudomonas diversity. Microbiology 146, 2345-2350.

Stackebrandt, E., Frederiksen, W., Garrity, G. M., Grimont, P. A. D., Kampfer, P., Maiden, M. C. J., Nesme, X., Rossello-Mora, R., Swings, J. \& other authors (2002). Report of the ad hoc committee for the reevaluation of the species definition in bacteriology. Int J Syst Evol Microbiol 52, 1043-1047.

Vandamme, P., Pot, B., Gillis, M., de Vos, P., Kersters, K. \& Swings, J. (1996). Polyphasic taxonomy, a consensus approach to bacterial systematics. Microbiol Rev 60, 407-438.

Vanparys, B., Heylen, K., Lebbe, L. \& De Vos, P. (2006). Pseudomonas peli sp. nov. and Pseudomonas borbori sp. nov., isolated from a nitrifying inoculum. Int J Syst Evol Microbiol 56, 1875-1881.

Versalovic, J., Koeuth, T. \& Lupski, J. R. (1991). Distribution of repetitive DNA sequences in eubacteria and application to fingerprinting of bacterial genomes. Nucleic Acids Res 19, 6823-6831.

Versalovic, J., Schneider, M., de Brujin, F. J. \& Lupski, J. R. (1994). Genomic fingerprinting of bacteria using repetitive sequence-based polymerase chain reaction. Methods Mol Cell Biol 5, 25-40.

Yamamoto, S., Kasai, H., Arnold, D. L., Jackson, R. W., Vivian, A. \& Harayama, S. (2000). Phylogeny of the genus Pseudomonas: intrageneric structure reconstructed from the nucleotide sequences of gyrB and rpoD genes. Microbiology 146, 2385-2394. 